Paul Langerhans

\section{Paul Langerhans}

\section{$S$ Jolles}

\section{A historical perspective}

2 ul Langerhans (born Berlin, Germany, 25 July 1847; died Funchal, Madeira, 20 July 1888), the son of a well known physician in Berlin, studied medicine at the Universities of Jena and Berlin, graduating in 1869. He made an outstanding contribution to medicine while still an undergraduate student, when he described a new epidermal cell in a paper entitled "On the nerves of the human skin". ${ }^{1}$ Using the gold chloride techniques of Julius Cohnheim, he described the dendritic, non-pigmentary cells in the epidermis that he regarded as intraepidermal receptors for extracutaneous signals of the nervous system. These cells were an enigma to dermatologists for over a century before the recognition of their immunological function and importance. The precision of his observation and description of the cells seems incredible when his drawings of 1868 , made with the use of a primitive light microscope, are compared with the reproduction obtained today with immunofluorescence (fig 1). After more than a century without appreciable progress into the nature, importance, and function of these cells, in 1973 Dr Inga Silberberg discovered that the epidermal Langerhans cells represent the most peripheral outpost of the immune system. ${ }^{2}$ Today, Langerhans cells are the best studied immature dendritic cell subset.

Paul Langerhans also made the first careful and detailed description of the microscopic structure of the pancreas. He described nine different types of cells including small, irregularly shaped, polygonal cells without granules, which formed numerous "zellhaufen"literally cell heaps-measuring 0.1 to $0.24 \mathrm{~mm}$ in diameter, throughout the gland. Langerhans refrained from making a hypothesis as to the nature and importance of these cells. In 1893, the French histologist GE Languesse named these spots "ilots de Langerhans"; the insulin secreting function of these cells was established later.

Another important contribution, made with FA Hoffmann in Virchow's laboratory, dealt with the macrophage system. He and Hoffmann studied the intravital storage of cinnabar injected intravenously into rabbits and guinea pigs. They were able to show that cinnabar was taken up by white blood corpuscles but never red. They also demonstrated deposits of cinnabar in fixed cells of the bone marrow, capillaries, and connective tissue of the liver. This was one of the pioneering investigations that later led to Aschoff's concept of the reticuloendothelial system.

He was also involved in zoological studies resulting in the publication of papers on the heart of amphibious animals, eye of lamprey, and numerous others. $^{3-5}$ The investigation of the lamphrey is a complete book of 115 pages with 11 plates. ${ }^{5}$ After settling on his "prison island" of Madeira because of pulmonary tuberculosis, he did not stop his scientific work. He continued his zoological studies of the fauna of the Canary Islands and Madeira, leading to a series of publications representing a remarkable contribution to the literature on invertebrates. Not surprisingly, Langerhans was also interested in his own disease and published two papers on tuberculosis. ${ }^{67}$ In Madeira he practised medicine in the capital, Funchal, where in 1888 he died of a kidney infection.

When considering all of Paul Langerhans's achievements during his short life, his enduring fame seems quite proper.

\section{J Clin Pathol 2002;55:243}

\section{Authors' affiliations}

S Jolles, Division of Cellular Immunology, The National Institute for Medical Research, The Ridgeway, Mill Hill, London NW7 IAA, UK

Correspondence to: $\operatorname{Dr} \mathrm{S}$ Jolles, National Institute for Medical Research, Division of Cellular Immunology, The Ridgeway, Mill Hill, London NW7 1AA, UK; sjolles@nimr.mrc.ac.uk

\section{REFERENCES}

1 Langerhans $\mathbf{P}$. Uber die nerven der menschlichen haut. Archives of Pathological Anatomy 1868:44:325-37.

2 Silberberg I. Apposition of mononuclear cells to Langerhans cells in contact allergic reactions. Acta Derm Venereol 1973;53:1-12.

3 Langerhans P. Mitteilungen veber das Auge des Neunauges. 8. Section fuer Anatomie und Pysiologie. Tageblatt der Versammlung deutscher Naturforsher und Aerzte 1873:69.

4 Langerhans P. Zur Histologie des Herzens. Archives of Pathological Anatomy 1873;58:65-83.

5 Langerhans P. Untersuchungen uber Petromyzon-Planery. Freiburg: C. Tromer, 1873

6 Langerhans P. Zur Aetiologie der Phythise. Archives of Pathological Anatomy 1884;97:289-306.

7 Langerhans P. Ueber die Verbreitung der Tuberkelbacillen im Koerper. Archives of Pathological Anatomy 1888;1 12:16-25.
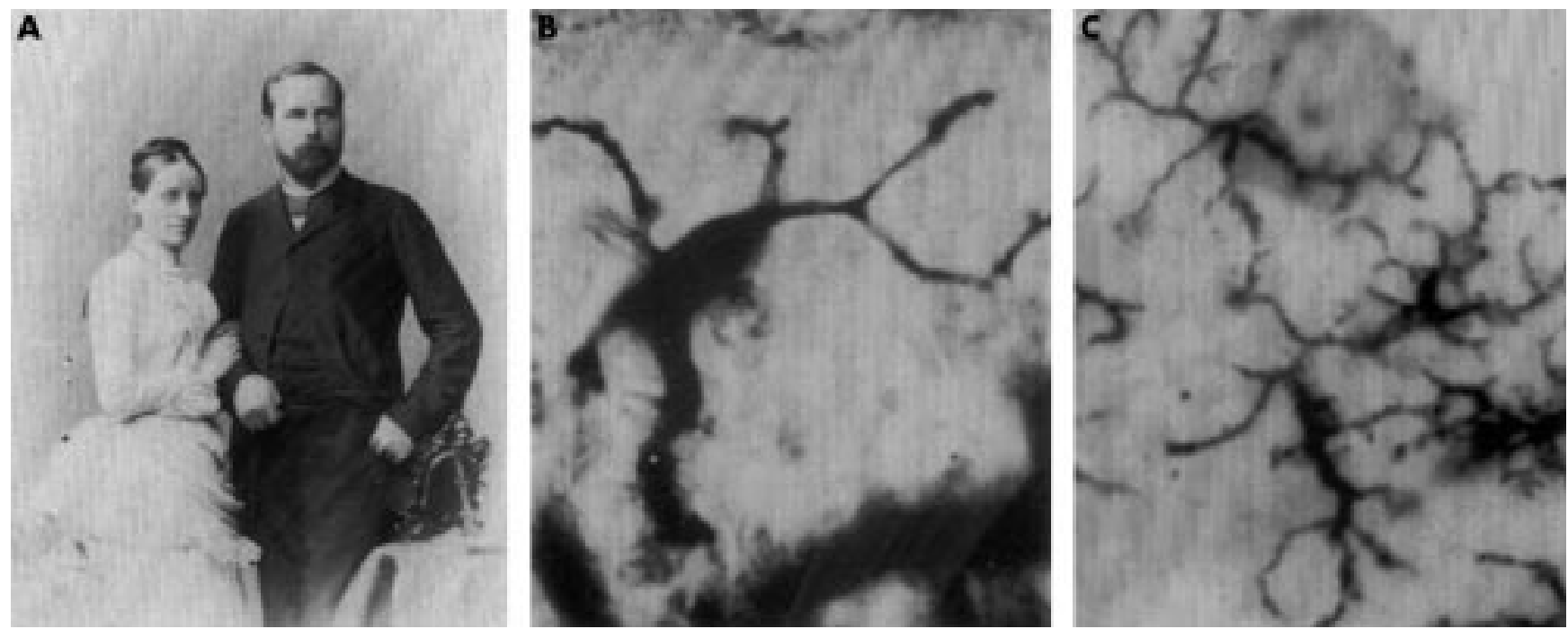

Figure 1 Paul Langerhans with his wife (A) adjacent to the remarkable picture of his cell (B): the Langerhans cell. (C) This panel shows a modern immunofluorescent digital image, which despite the technology and almost 150 years adds little to his original depiction. 